\title{
Fetal Control of Calcium Transport across the Rat Placenta
}

\author{
N. R. ROBINSON, C. P. SIBLEY, M. Z. MUGHAL, AND R. D. H. BOYD \\ Departments of Child Health [N.R.R., C.P.S., M.Z.M., R.D.H.B.] and Physiological Sciences [N.R.R., C.P.S.], \\ University of Manchester, St. Mary's Hospital, Manchester, England
}

\begin{abstract}
Control of maternofetal calcium transfer across the in situ perfused rat placenta at day 21 of gestation (term $23 \mathrm{~d}$ ) was investigated in both intact fetuses and those parathyroidectomized by decapitation on day 19. Decapitation resulted in significant fetal hypocalcemia. Injection of fetuses subcutaneously through the uterine wall with $0.43 \mu \mathrm{g}$ bovine (b) $\mathrm{PTH}(1-84), 20 \mathrm{ng}$ $1,25(\mathrm{OH})_{2} \mathrm{D}_{3}$ or $10 \mu \mathrm{L}$ of the appropriate diluent resulted $2 \mathrm{~h}$ later in a raised fetal blood ionized $\mathrm{Ca}$ concentration only with bPTH(1-84) in both normal and decapitated fetuses. Fetal decapitation caused a significant $(p<0.001)$ fall in the clearance of ${ }^{45} \mathrm{Ca}$ across the placenta $\left(\mathrm{K}_{\mathrm{mf}}{ }^{45} \mathrm{Ca}\right)$, which was significantly $(p<0.05)$ reversed after fetal bPTH(1-84) and 1,25 dihydroxy vitamin $\mathrm{D}_{3}\left(1,25(\mathrm{OH})_{2}\right.$ $\mathrm{D}_{3}$ ) injection, but not back to normal levels. There was no effect of either hormone on $\mathrm{K}_{\mathrm{mf}}{ }^{45} \mathrm{Ca}$ in placentas from intact fetuses, or on $\mathrm{K}_{\mathrm{mf}}{ }^{51} \mathrm{Cr}$-EDTA (used as an extracellular marker) in either group. When $4 \mathrm{ng} / \mathrm{mL} r\left[\mathrm{Nle}^{8,21}, \mathrm{Tyr}^{34}\right]$ PTH(1-34), $50 \mathrm{pg} / \mathrm{mL} 1,25(\mathrm{OH})_{2} \mathrm{D}_{3}$ or the appropriate diluent was perfused through placentas the only response observed was a significant $(p<0.05)$ increase in $K_{\mathrm{mf}}{ }^{45} \mathrm{Ca}$ with $1,25(\mathrm{OH})_{2} \mathrm{D}_{3}$ perfusion in placentas from decapitated fetuses, $K_{m f}{ }^{5} \mathrm{Cr}$-EDTA being unchanged. Finally, perfusion with $10^{-5} \mathrm{M}$ forskolin (an activator of adenylate cyclase) stimulated $\mathrm{K}_{\mathrm{mf}}{ }^{45} \mathrm{Ca}$ in placentas from both normal and decapitated fetuses. Although there was also some effect on $\mathrm{K}_{\mathrm{mf}}^{51} \mathrm{Cr}$-EDTA in the latter, there was none in the placentas from normal fetuses, and here the effect on $\mathrm{K}_{\mathrm{mf}}{ }^{45} \mathrm{Ca}$ was dose dependent with an initial response at $10^{-6} \mathrm{M}$. It is therefore suggested that fetal PTH and $1,25(\mathrm{OH})_{2} \mathrm{D}_{3}$ may play a permissive role in the control of maternofetal calcium transfer and that other hormones which act via cAMP may be involved in the acute regulation of calcium transfer under normal conditions. (Pediatr Res 26: 109-115, 1989)
\end{abstract}

\section{Abbreviations}

bPTH (1-84), bovine PTH 1-84

FiCa, fetal blood ionized calcium concentration

$\mathrm{K}_{\mathrm{mf}}{ }^{45} \mathrm{Ca}$, unidirectional maternofetal clearance for ${ }^{45} \mathrm{Ca}$

$\mathbf{K}_{\mathrm{mf}}{ }^{{ }^{51}} \mathrm{Cr}$-EDTA, unidirectional maternofetal clearance for ${ }^{51} \mathrm{Cr}$-EDTA

MiCa, maternal blood ionized Ca concentration

PTHrP, PTH-related peptide

r[Nle $\left.{ }^{8,21}, \mathrm{Tyr}^{34}\right] \mathrm{PTH}(1-34)$, synthetic rat parathyroid hormone 1-34 amide

$1,25(\mathrm{OH})_{2} \mathrm{D}_{3}, 1,25$ dihydroxy vitamin $\mathrm{D}_{3}$

Received December 14, 1988; accepted April 12, 1989.

Correspondence, and reprints Dr. N. R. Robinson, Department of Child Health University of Manchester, St Mary's Hospital, Hathersage Road, Manchester M13 OJH, England.

Supported by the North Western Regional Health Authority. s.c., subcutaneous

$\mathrm{J}_{\mathrm{mf}} \mathrm{Ca}$, unidirectional maternofetal flux

In the sheep there is evidence that prolactin may stimulate and calcitonin reduce net maternofetal calcium transfer $(1,2)$, and studies on fetally perfused sheep placenta suggests that PTHrP may stimulate calcium transfer (3). There have been few direct studies in other species (4) although fetal calcium homeostasis also appears to be autonomous in the rat. Thus PTH (5) and calcitonin (6) do not appear to cross the rat placenta and are presumably of fetal or placental $(7,8)$ origin, and the fetal parathyroids (9) and thyroid "C" cells (10) are active in utero. Fetal $1,25(\mathrm{OH})_{2} \mathrm{D}_{3}$ may be derived from the mother across the placenta (11), be produced by the placenta itself (12), or by the fetal kidney (13), although the fall in plasma $1,25(\mathrm{OH})_{2} \mathrm{D}_{3}$ concentration after bilateral nephrectomy of the sheep fetus (14) suggests that in this species the fetal kidney is the major source.

Stulc and Stulcová (15) have described a method for perfusing the fetal side of the rat placenta and demonstrated by this method active maternofetal calcium transport quantitatively similar to that found in vivo. We have also recently investigated the passive permeability of the rat placenta and found that not only is it similar per unit placental wt. to that of other haemochorial placentas but that it is not altered by fetal side perfusion (16). The perfused rat placenta therefore seems a promising model with which to investigate fetal control of calcium transfer. In our study the effects of PTH and $1,25(\mathrm{OH})_{2} \mathrm{D}_{3}$ have been studied both by injection into fetuses with subsequent perfusion of their placentas for measurement of calcium transfer and in other experiments by directly perfusing the hormones through the placentas. We have also investigated whether forskolin, a stimulator of adenylate cyclase (17), could alter calcium transfer when perfused through the placenta. Experiments with all three agents, PTH, $1,25(\mathrm{OH})_{2} \mathrm{D}_{3}$, and forskolin have been carried out both with normal fetuses and with those which have been previously decapitated (18) as a means of removing the fetal parathyroids and lowering fetal plasma calcium concentration.

\section{MATERIALS AND METHODS}

Animals and General Procedures. Two groups of female pregnant Sprague-Dawley rats (Charles River, Manston, Kent, England) were used for all experiments described (females were left overnight with a male and if vaginal plugs were found in the morning then this was designated day 1 of gestation; term $23 \mathrm{~d}$ ). One group of animals was left to develop as normal until d 21 of gestation when perfusions were carried out. In the other group fetal decapitation was carried out by the method of Jost (18) on d 19 of gestation. These rats were briefly anaesthetised with ether and the uterus was exposed at laparotomy. Heads of alternate fetuses were delivered through a loose purse string suture previ- 
ously placed in the uterus and the loop was then tightened so as to simultaneously sever the head and close the uterus. The abdomen was then closed and the animal allowed to recover.

For perfusion on $\mathrm{d} 21$ of gestation both control and previously fetally decapitated rats were anaesthetized intraperitoneally with $110 \mathrm{mg} / \mathrm{kg}$ sodium thiobutabarbital (Inactin, BYK Gulden, Hamburg, FRG). Animals were maintained with maternal rectal temperatures close to $37^{\circ} \mathrm{C}$ throughout the experiments using a heated pad and warm dissection lamp; in the first group of studies (experiment 1, with bPTH(1-84)) perfused before the importance of close temperature control was established, temperature control was less accurate and rectal temperatures in similarly studied animals ranged from $34-37^{\circ} \mathrm{C}$. The maternal carotid artery and jugular vein were catheterized, the uterus opened and immediately fetal blood was taken by axial incision for measurement of ionized calcium using a Radiometer ICA1 (Radiometer, Copenhagen; corrected to pH 7.4). Maternal blood was also taken at the end of each experiment for measurement of MiCa. Placentas were then perfused via the umbilical artery and vein (there is only one vein in the rat) using the method of Stulc and Stulcova (15) as previously detailed (16). The perfusate was a modified Krebs Ringer solution containing (mM) NaCl (118), $\mathrm{KCl}(4.7), \mathrm{NaHCO}_{3}(24.9), \mathrm{CaCl}_{2}-2 \mathrm{H}_{2} \mathrm{O}(1.25), \mathrm{KH}_{2} \mathrm{PO}_{4}$ (1.18), $\mathrm{MgSO}_{4^{-}} 7 \mathrm{H}_{2} \mathrm{O}$ (1.18), glucose (11), and $3.5 \%$ dextran (40,000 mol wt; Sigma Chemical Co., Poole, Dorset, England), warmed to $37^{\circ} \mathrm{C}$, and perfused at a rate of $0.5 \mathrm{~mL} / \mathrm{min}$; venous effluent was collected at 4-min intervals after a single passage through the placenta. ${ }^{45} \mathrm{Ca}(0.37-1.5 \mathrm{GBq} / \mathrm{mg}$ calcium $)$ and ${ }^{51} \mathrm{Cr}-$ EDTA (37-74 MBq/mg chromium; used as a diffusional marker) (Amersham International plc, Bucks., England) were injected into the maternal jugular venous catheter at time zero (approximately 5 min after the start of perfusion) and maternal carotid blood samples $(0.5 \mathrm{~mL})$ were taken throughout the experiment for radioactive counting. ${ }^{45} \mathrm{Ca}$ activity was measured using a Packard 2000Ca (Packard Instrument Co., Downers Grove, IL) with channels set to exclude ${ }^{51} \mathrm{Cr}$ counts. ${ }^{51} \mathrm{Cr}$ was counted using a Packard $800 \mathrm{C} \gamma$-counter. Samples of perfusate were similarly analyzed for both ${ }^{45} \mathrm{Ca}$ and ${ }^{51} \mathrm{Cr}$. The criteria for a successful preparation were defined as: perfusate recovery $95-100 \%$ by wt, maternal blood pressure of more than $8.6 \mathrm{kPa}(65 \mathrm{~mm} \mathrm{Hg})$, perfusion pressure less than $5.6 \mathrm{kPa}(40 \mathrm{~mm} \mathrm{Hg})$ and the placenta was bright red and uniformly perfused at the end of the experiment. There were no exclusions on this basis in the present series of experiments. Fetuses were weighed with the cord cut off after a brief blotting. Placentas were weighed after triming free of membranes and brief blotting.

$\mathrm{K}_{\mathrm{mf}}{ }^{45} \mathrm{Ca}$ and $\mathrm{K}_{\mathrm{mf}}{ }^{51} \mathrm{Cr}$-EDTA were defined as:

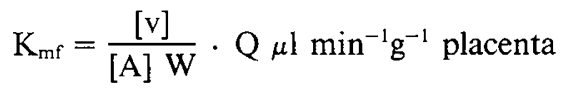

where $[\mathrm{v}]$ is the concentration of radioisotope in fetal venous outflow, $\mathrm{Q}$ is the perfusion flow rate, $[\mathrm{A}]$ is the concentration of tracer in the maternal arterial blood (extrapolated from the graph of isotope decay in the maternal blood, taken at the mid-time point of each perfusate collection) and $W$ is the wet wt of the placenta. $\mathrm{K}_{\mathrm{mf}}$ was taken to have achieved a steady state when there was no significant rise in its calculated value between adjacent control collection periods.

Experiments. Fetal injection with bPTH(1-84) and 1,25(OH) $D_{3}$. After anaesthesia and uterus exposure on d 21 , intact and decapitated fetuses were injected s.c. into the back of the fetal body through the uterine wall, with 1$) 1.0 \mathrm{IU}(0.43 \mu \mathrm{g})$ bPTH(184) (National Institute for Biological Standards, London, England) in a $1.0 \%$ sodium acetate and $0.1 \%$ BSA (Sigma, protease free, 7906) solution, made up to $\mathrm{pH} 4$ with glacial acetic acid, 2) $20 \mathrm{ng} 1,25(\mathrm{OH})_{2} \mathrm{D}_{3}$ (Roche Products, Welwyn Garden City, England) in a $1: 10095 \%$ alcohol/0.9\% saline solution, or 3) 10 $\mu \mathrm{L}$ of the appropriate diluent (i.e., either of the above solutions without hormone). The animals were then maintained anaesthe- tized and warm for $2 \mathrm{~h}$ after which the FiCa was measured and placentas perfused. $\mathrm{K}_{\mathrm{mf}}{ }^{45} \mathrm{Ca}$ and $\mathrm{K}_{\mathrm{mf}}{ }^{51} \mathrm{Cr}$-EDTA were measured as described above. A crude measure of bPTH(1-84) bioactivity was obtained by injecting $0.58 \mathrm{IU}(0.25 \mu \mathrm{g})$ s.c. into intact fetuses and measuring FiCa 3 h later.

Placental perfusion with $r\left[\mathrm{Nle}^{8,21}, \mathrm{Tyr}^{34}\right] \mathrm{PTH}(\mathrm{I}-34)$ or $\mathrm{I}, 25(\mathrm{OH})_{2}$ $D_{3}$. In this series placentas of control and previously decapitated fetuses were again studied. Two control perfusate collections were made initially at 4-8 and 8-12 min and then either 1) 4 $\mathrm{ng} / \mathrm{mL}$ r[Nle $\left.{ }^{8,21}, \mathrm{Tyr}^{34}\right] \mathrm{PTH}(1-34)$ (Peninsula Laboratories Inc., Belmont, CA) which is reported to be more stable and less prone to oxidative degradation than bPTH(1-84) (19) in 1:10 diluent/ Krebs (1.0\% sodium acetate, $0.1 \%$ BSA (Sigma, protease free A4378) at $\mathrm{pH}$ 4), 2) $50 \mathrm{pg} / \mathrm{mL} 1,25(\mathrm{OH})_{2} \mathrm{D}_{3}$ (Roche Products) in a $1: 10095 \%$ alcohol $/ 0.9 \%$ saline solution plus $0.2 \%$ proteasefree bovine albumin, or 3) the appropriate diluent, were introduced into the perfusate (via a side arm in the perfusion tubing close to the placenta using an infusion pump at a rate of 0.052 $\mathrm{mL} / \mathrm{min})$ for another $40 \mathrm{~min}$. BSA $(0.1 \%$, protease free) was added to the Krebs Ringer in these experiments and the perfusion tubing primed with this solution for 10-15 min before the start of placental perfusion with the aim of albumin acting as a carrier molecule and preventing the hormones sticking to the tubing. For perfusion with $1,25(\mathrm{OH})_{2} \mathrm{D}_{3}$ a higher concentration of BSA $(0.3 \%)$, was added to the perfusate in order to solubilize $1,25(\mathrm{OH})_{2} \mathrm{D}_{3}$ and to act as a carrier in the absence of vitamin $\mathrm{D}$ binding protein (20).

As there was a lag time of approximately $5 \mathrm{~min}$ before hormone or diluent reached the umbilical artery, the next two perfusate collections of this period were not analyzed in either group, after which eight 4-min collections were made and data were expressed as the percentage change in $\mathrm{K}_{\mathrm{mf}}$ (with hormone or diluent) from the mean $\mathrm{K}_{\mathrm{mf}}$ of the two control collection periods. A measure of $r\left[\mathrm{Nle}^{8,21}, \mathrm{Tyr}^{34}\right] \mathrm{PTH}(1-34)$ bioactivity was obtained by injecting $4 \mathrm{ng}$ into intact rat fetuses and measuring $\mathrm{FiCa} 2 \mathrm{~h}$ later.

Placental perfusion with forskolin. Placentas from both intact and decapitated fetuses were perfused and two 4-min control perfusate collections were made at 4-8 and 8-12 min after radioisotope injection. Then either 1 ) $10^{-4} \mathrm{M}$ forskolin (Calbiochem, Behring Diagnostics, Cambridge Bioscience, England) in a 1:10 95\% alcohol $/ 0.9 \%$ saline solution, or 2) $1: 1095 \%$ alcohol/ $0.9 \%$ saline solution alone, were introduced into the perfusate via the side-arm as in experiment 2 . The final concentration of forskolin in the perfusate as it entered the umbilical artery was $10^{-5} \mathrm{M}$. Again, because of the lag time between switching on the side-arm infusion pump and drug or diluent actually entering the umbilical artery the next two perfusate collections were not analyzed. The next five 4-min collections were then taken for radioisotope analysis. Data are expressed as the percentage change in $\mathrm{K}_{\mathrm{mf}}$ (with $10^{-5} \mathrm{M}$ forskolin or diluent) from the mean $\mathrm{K}_{\mathrm{mf}}$ of the two control collection periods. This investigation was extended in placentas from intact fetuses only, by perfusion with $10^{-7} \mathrm{M}, 10^{-6} \mathrm{M}$ and $10^{-4} \mathrm{M}$ forskolin (final concentrations).

Statistics. Data are shown in all cases as the mean \pm the SEM and normality of distribution has been confirmed. Hence, statistical comparisons have been made using the Student' $t$ test, paired or unpaired as appropriate or ANOVA and Duncan's multiple range test. Individual experimental animals were informally randomized to active agent or diluent in the various experimental groups by selecting the experimental protocol before the animal was brought to the laboratory.

\section{RESULTS}

Fetal and placental wt. Fetal and placental weights for intact fetuses were $3.35 \pm 0.04$ and $0.46 \pm 0.01 \mathrm{~g}(n=98)$, respectively. Placental wt for previously decapitated fetuses were not significantly different $(0.43 \pm 0.01 \mathrm{~g})$. Decapitated fetal weights were $1.96 \pm 0.05 \mathrm{~g}(n=107)$. 
A

$\square+$ diluent

$\triangle+1.0$ i.u. bPTH $(1-84)$
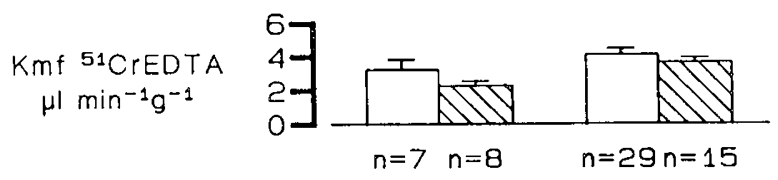

$K m f{ }^{45} \mathrm{Ca}$
$\mu 1 \min ^{-1} g^{-1}$

$$
\text { pinin } 9
$$

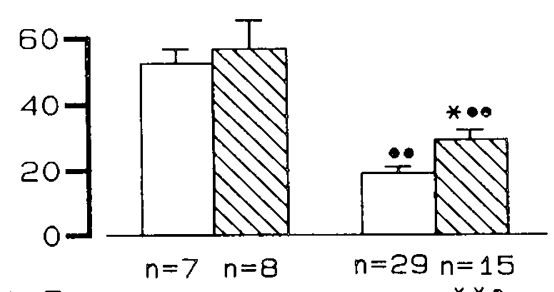

B

Kmf ${ }^{51}$ CrEDTA $\mu l \min ^{-1} g^{-1}$

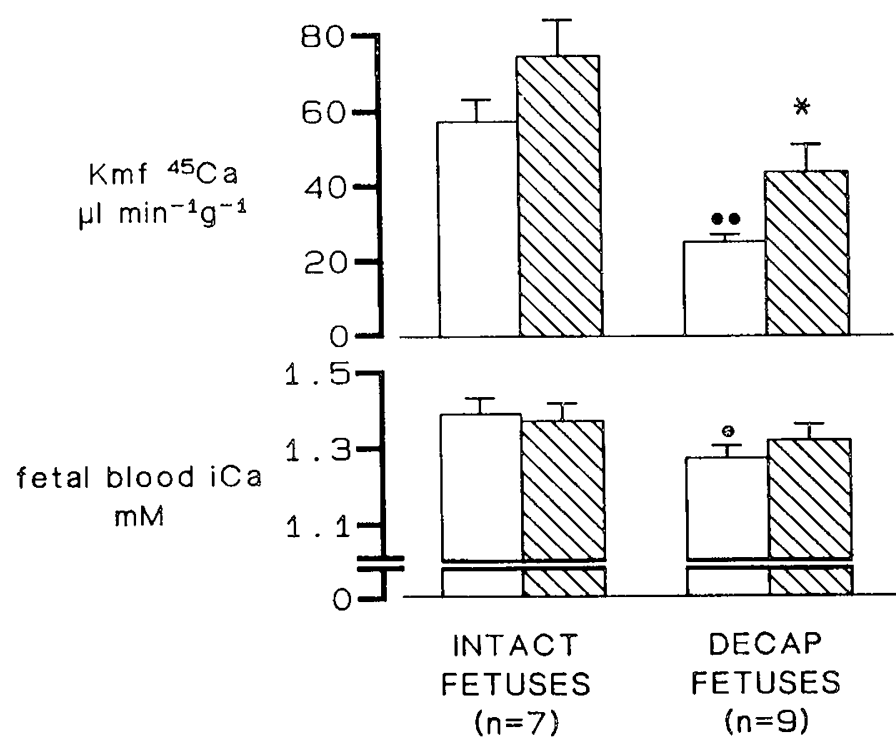

Fig. 1. The effect of s.c. injection, $2 \mathrm{~h}$ before placental perfusion of A) $1.0 \mathrm{IU}(0.43 \mu \mathrm{g}) \mathrm{bPTH}(1-84)$ or its diluent, and $B) 20 \mathrm{ng} 1,25(\mathrm{OH})_{2} \mathrm{D}_{3}$ or its diluent, in intact or previously decapitated fetuses on $\mathrm{d} 21$ of gestation. Unpaired Student's $t$ test compares bPTH $(1-84) / 1,25(\mathrm{OH})_{2} \mathrm{D}_{3}$ versus diluent data $\left({ }^{*} p<0.05,{ }^{* *} p<0.01\right)$ and intact versus previously decapitated fetuses $(\cdot p<0.05, \cdots p<0.01)$ mean \pm SEM, $n=$ number of placentas).
Fetal injections with bPTH(1-84) and $1,25(\mathrm{OH})_{2} \mathrm{D}_{3}$. Comparison of fetuses in one horn injected with $0.58 \mathrm{IU}(0.25 \mu \mathrm{g})$ bPTH(1-84) to those in the other horn injected with diluent, showed a significant $(p<0.001)$ increase in FiCa with bPTH(184) (from $1.39 \pm 0.04 \mathrm{mM}, n=8$, to $1.69 \pm 0.04 \mathrm{mM}, n=8$ ) after $3 \mathrm{~h}$

Figure $1 A$ and $B$ show the effect of fetal injection of bPTH(184) and $1,25(\mathrm{OH})_{2} \mathrm{D}_{3}$ respectively on $\mathrm{K}_{\mathrm{mf}}{ }^{51} \mathrm{Cr}$-EDTA, $\mathrm{K}_{\mathrm{mf}}{ }^{45} \mathrm{Ca}$, and $\mathrm{FiCa}$, in intact and decapitated fetuses $2 \mathrm{~h}$ later. Fetal decapitation itself caused a significant $(p<0.001)$ fall in $\mathrm{FiCa}$ when compared to control intact fetuses.

Injection of bPTH(1-84), but not of $1,25(\mathrm{OH})_{2} \mathrm{D}_{3}$ increased $\mathrm{FiCa}$ above diluent in both decapitated and intact fetuses. Maternal MiCa was $1.25 \pm 0.03 \mathrm{mM}(n=8)$ in mothers of bPTH(1$84)$ injected intact fetuses compared to $1.12 \pm 0.04 \mathrm{mM}(n=7)$ in diluent controls by $2 \mathrm{~h}$ after injection $(p<0.05)$, and $1.25 \pm$ $0.03 \mathrm{mM}(n=15)$ in mothers of bPTH(1-84) injected decapitated fetuses compared to $1.15 \pm 0.02 \mathrm{mM}(n=27)$ in diluent controls $(p<0.01) . \mathrm{K}_{\mathrm{mf}}{ }^{51} \mathrm{Cr}$-EDTA was not significantly altered by fetal decapitation in the JPTH(1-84) study but was significantly increased by fetal decapitation in the $1,25(\mathrm{OH})_{2} \mathrm{D}_{3}$ study. Neither bPTH(1-84) nor $1,25(\mathrm{OH})_{2} \mathrm{D}_{3}$ altered $\mathrm{K}_{\mathrm{mf}}{ }^{11} \mathrm{Cr}$-EDTA significantly in either group. However, a significantly $(p<0.001$ decapitated versus intact) lower $\mathrm{K}_{\mathrm{mf}}{ }^{45} \mathrm{Ca}$ was associated with prior fetal decapitation in both studies and was in each case significantly ( $p<0.05$ compared to diluent) reversed by either bPTH( 1 84 ) or $1,25(\mathrm{OH})_{2} \mathrm{D}_{3}$, but not back up to control (intact fetus) levels. $\mathrm{K}_{\mathrm{mf}}{ }^{45} \mathrm{Ca}$ in placentas from intact fetuses was not altered by either hormone.

Placental perfusion with $r\left[N / l^{8,21}, T_{y r^{34}}\right] \mathrm{PTH}(1-34)$ and 1,25 $(\mathrm{OH})_{2} \mathrm{D}_{3} . \mathrm{r}\left[\mathrm{Nle}^{8,21}, \mathrm{Tyr}^{34}\right] \mathrm{PTH}(1-34)$ injection to intact fetuses in utero appeared active as it increased FiCA from $1.32 \pm 0.03 \mathrm{mM}$ $(n=12)$ to $1.51 \pm 0.03 \mathrm{mM}(n=12)$, when compared to diluent injection alone $(p<0.001)$

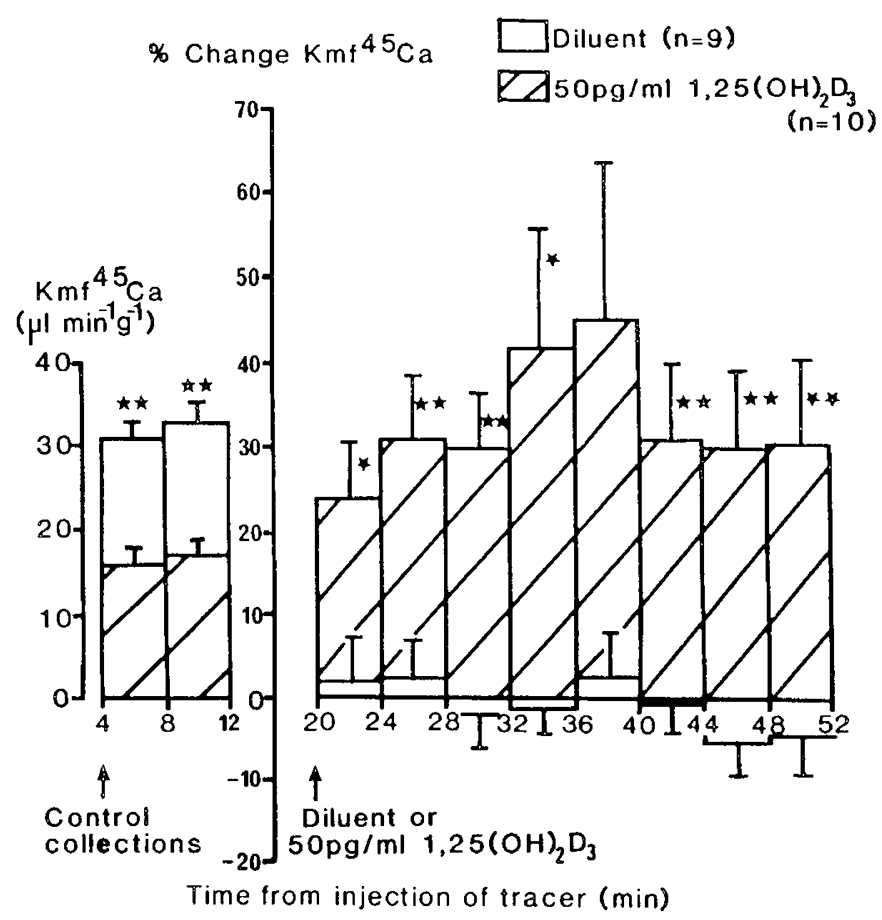

Fig. 2. $\mathrm{K}_{\mathrm{mf}}{ }^{45} \mathrm{Ca}$ : the effect of perfusion on $\mathrm{d} 21$ of gestation with 50 $\mathrm{pg} / \mathrm{mL} 1,25(\mathrm{OH})_{2} \mathrm{D}_{3}$ or its diluent on placentas from previously decapitated fetuses. Control data shown as absolute values $\left(\mu \mathrm{L} \min ^{-1} \mathrm{~g}^{-1}\right)$. Percentage change is the change in $\mathrm{K}_{\mathrm{mf}}{ }^{45} \mathrm{Ca}$ from the mean of the two control periods. Time zero is time of maternal injection with ${ }^{45} \mathrm{Ca}$. Unpaired Student's $t$ test compares $1,25(\mathrm{OH})_{2} \mathrm{D}_{3}$ versus diluent groups for each collection period $\left({ }^{*} p<0.05 ;{ }^{* *} p<0.01\right.$ ) (mean $\pm \mathrm{SEM}, n=$ number of placentas). 


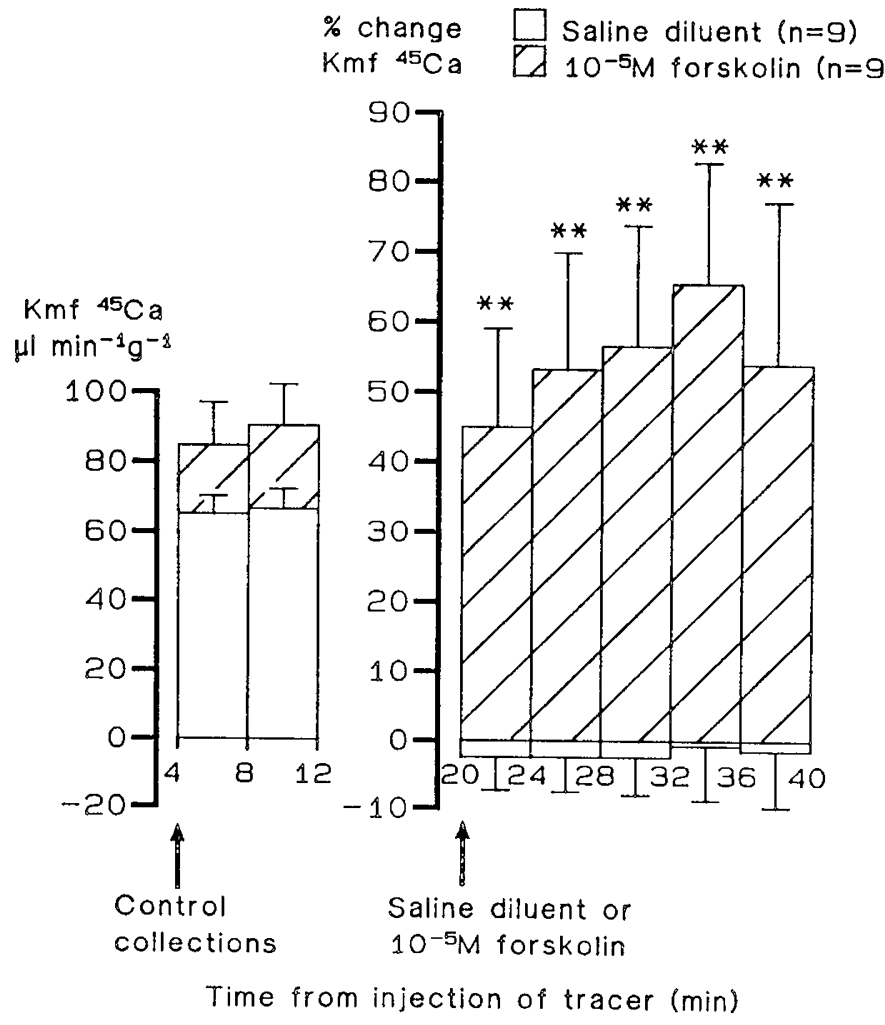

Fig. 3. $\mathrm{K}_{\mathrm{mf}}{ }^{45} \mathrm{Ca}$ : the effect of perfusion on $\mathrm{d} 21$ of gestation with $10^{-5}$ $\mathrm{M}$ forskolin or its diluent on placentas from intact fetuses. Control data shown as absolute values $\left(\mu \mathrm{L} \mathrm{min}^{-1} \mathrm{~g}^{-1}\right)$. Percentage change is the change in $\mathrm{K}_{\mathrm{mf}}{ }^{45} \mathrm{Ca}$ from the mean of the two control periods. Time zero is time of maternal injection with ${ }^{45} \mathrm{Ca}$. Unpaired Student's $t$ test compares $10^{-5}$ $\mathrm{M}$ forskolin versus diluent for each collection period $\left({ }^{* *} p<0.01\right.$ ) (mean \pm SEM, $n=$ number of placentas). There were no changes in the $\mathrm{K}_{\mathrm{mf}}{ }^{51} \mathrm{Cr}-$ EDTA measured in these experiments (not illustrated).

In this series $\mathrm{K}_{\mathrm{mf}}{ }^{45} \mathrm{Ca}$ was again lower in placentas from decapitated compared with intact fetuses $(p<0.001)$ but perfusion with $\mathrm{r}\left[\mathrm{Nle}^{8,21}, \mathrm{Tyr}^{34}\right] \mathrm{PTH}(1-34)$ had no significant effect on $\mathrm{K}_{\mathrm{mf}}{ }^{45} \mathrm{Ca}$ or $\mathrm{K}_{\mathrm{mf}}^{51} \mathrm{Cr}$-EDTA across placentas from either group. The perfusion of placentas from intact fetuses with $1,25(\mathrm{OH})_{2} \mathrm{D}_{3}$ also had no significant effect on either $\mathrm{K}_{\mathrm{mf}}{ }^{51} \mathrm{Cr}$-EDTA or $\mathrm{K}_{\mathrm{mf}}{ }^{45} \mathrm{Ca}$.

In the group of animals with decapitated fetuses chosen (at random) to receive $1,25(\mathrm{OH})_{2} \mathrm{D}_{3}$ or its diluent, $\mathrm{K}_{\mathrm{mf}}{ }^{45} \mathrm{Ca}$ was again lower than with intact fetuses $(p<0.001)$ and $\mathrm{K}_{\mathrm{mf}}^{51} \mathrm{Cr}$ EDTA was significantly higher $(p<0.01)$. Unfortunately, there was also a difference between those chosen for subsequent administration of $1,25(\mathrm{OH})_{2} \mathrm{D}_{3}$ or diluent in the control values of $\mathrm{K}_{\mathrm{mf}}{ }^{51} \mathrm{Cr}$-EDTA, which were significantly higher $(p<0.05)$ in the group that was to receive $1,25(\mathrm{OH})_{2} \mathrm{D}_{3}$ than in the group that was to receive diluent (not illustrated). The opposite was true for $\mathrm{K}_{\mathrm{mf}}{ }^{45} \mathrm{Ca}$, with control values significantly $(p<0.01)$ higher in the group to receive diluent (Fig. 2). Nevertheless, the $1,25(\mathrm{OH})_{2} \mathrm{D}_{3}$ caused a significantly greater change from the control value of $\mathrm{K}_{\mathrm{mf}}{ }^{45} \mathrm{Ca}$ as compared to diluent perfusion, whether measured as percent change (Fig. 2) or in absolute terms. Mean $\mathrm{K}_{\mathrm{mf}}^{51} \mathrm{Cr}$-EDTA rose as a function of time in both the $1,25(\mathrm{OH})_{2} \mathrm{D}_{3}$ perfusion group and its diluent control but there was no difference between the two.

Placental perfusion with forskolin. Figure 3 shows the effect on $\mathrm{K}_{\mathrm{mf}}{ }^{45} \mathrm{Ca}$, of perfusion of placentas from intact fetuses with $10^{-5}$ $\mathrm{M}$ forskolin or its diluent alone. There were no significant differences in $\mathrm{K}_{\mathrm{mf}}$ for either tracer between the first and second control period, or between the two groups, i.e. those which were to receive $10^{-5} \mathrm{M}$ forskolin and those which were to receive saline diluent. Forskolin had no effect on $\mathrm{K}_{\mathrm{mf}}{ }^{51} \mathrm{Cr}$-EDTA (data not shown), but significantly $(p<0.01)$ increased $\mathrm{K}_{\mathrm{mf}}^{45} \mathrm{Ca}$ both

\author{
Saline diluent $(n=11)$ \\ $10^{-5} \mathrm{M}$ forskolin $(n=15)$ \\ \% Change $\mathrm{Kmf}^{51} \mathrm{Cr}$-EDTA
}

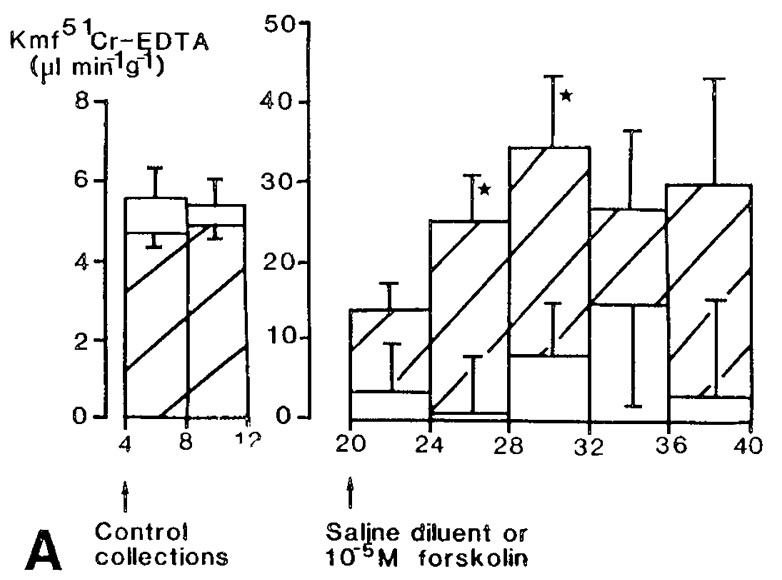

Time from injection of iracer $(\mathrm{min})$

Saline diluent $(n=11)$

$10^{-5} \mathrm{M}$ forskolin $(n=15)$

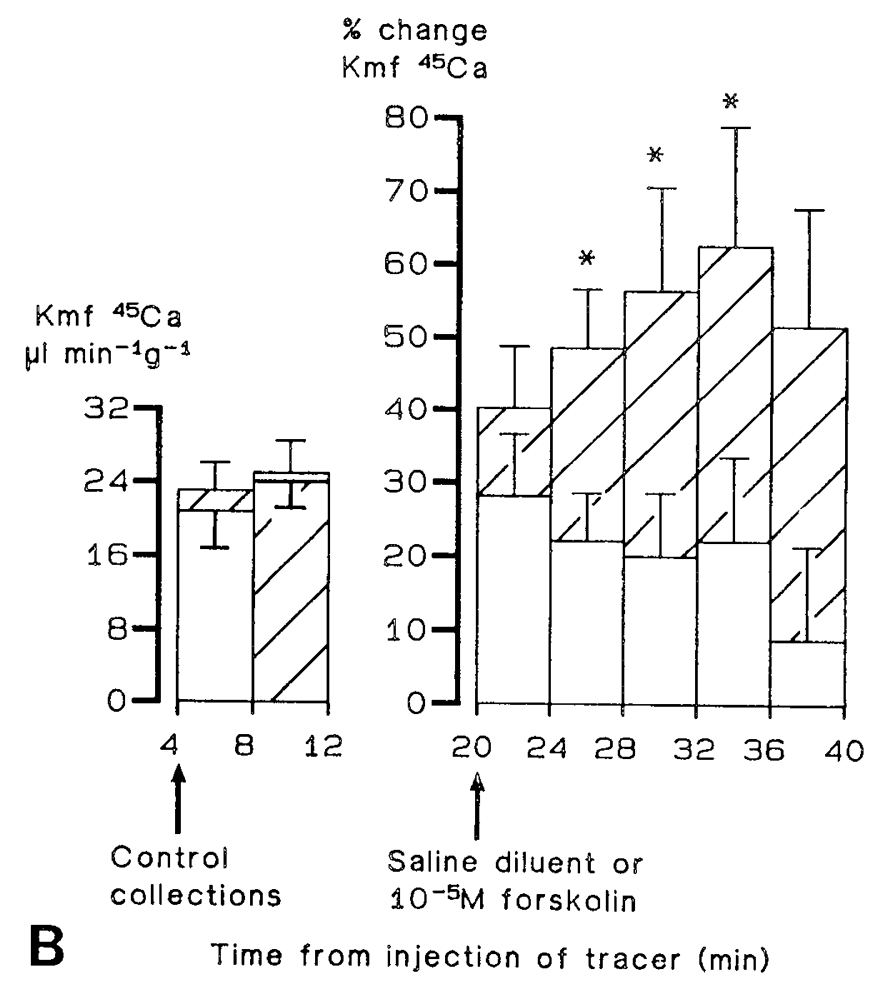

Fig. 4. The effect of perfusion on $\mathrm{d} 21$ of gestation with $10^{-5} \mathrm{M}$ forskolin or its diluent on placentas from previously decapitated fetuses. $A, \mathrm{~K}_{\mathrm{mf}}{ }^{51} \mathrm{Cr}$-EDTA and $B, \mathrm{~K}_{\mathrm{mf}}{ }^{45} \mathrm{Ca}$. Control data shown as absolute values $\left(\mu \mathrm{L} \min ^{-1} \mathrm{~g}^{-1}\right)$. Percentage change is the change in $\mathrm{K}_{\mathrm{mf}}{ }^{51} \mathrm{Cr}$-EDTA/ $\mathrm{K}_{\mathrm{mf}}{ }^{45} \mathrm{Ca}$ from the mean of the two control periods. Time zero is time of maternal injection with tracer. Unpaired Student's $t$ test compares $10^{-5}$ $\mathrm{M}$ forskolin versus diluent for each collection period $\left({ }^{*}<0.05\right)($ mean \pm SEM, $n=$ number of placentas).

above the control period values and when compared to the percentage change with saline diluent (Fig. 3).

The data for placentas of previously decapitated fetuses are shown in Figures $4 A$ and $B .10^{-5} \mathrm{M}$ forskolin significantly ( $p<$ 
A
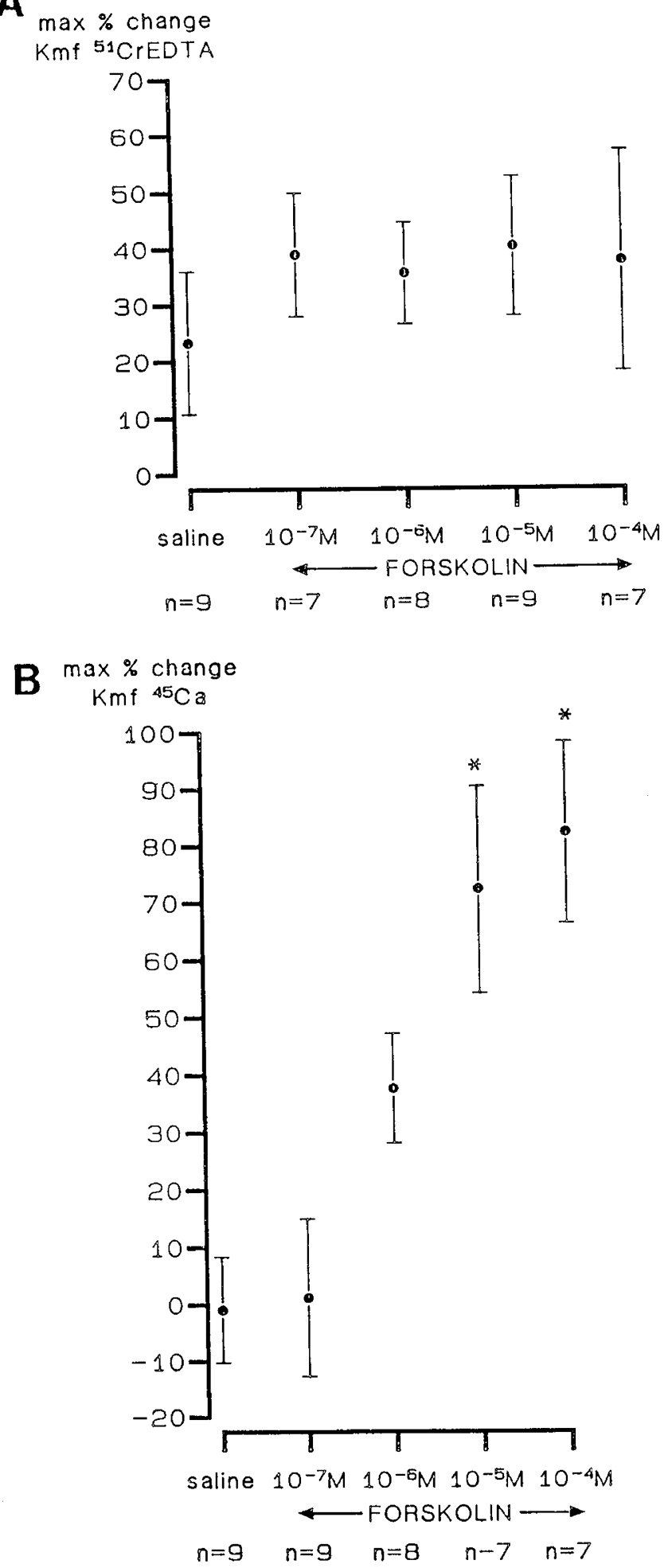

Fig. 5. Forskolin dose response curve. $A, \mathrm{~K}_{\mathrm{mf}}{ }^{51} \mathrm{Cr}$-EDTA and $B$, $\mathrm{K}_{\mathrm{mf}}{ }^{45} \mathrm{Ca}$. Mean maximal percentage change in $\mathrm{K}_{\mathrm{mf}}{ }^{51} \mathrm{Cr}-\mathrm{EDTA} / \mathrm{K}_{\mathrm{mf}}{ }^{45} \mathrm{Ca}$ over control as a function of perfusate forskolin concentration, in placentas from intact fetuses on d 21 of gestation. Each placenta was perfused at one concentration only. $\mathrm{K}_{\mathrm{mf}}{ }^{51} \mathrm{Cr}$-EDTA values are not significantly different from the saline diluent. ANOVA and Duncan's multiple range test compares the mean maximum percentage change in $\mathrm{K}_{\mathrm{mf}}{ }^{45} \mathrm{Ca}$ with $10^{-4} \mathrm{M}, 10^{-5} \mathrm{M}, 10^{-6} \mathrm{M}$, and $10^{-7} \mathrm{M}$ versus diluent $\left({ }^{*} p<0.01\right)$ (mean $\pm \mathrm{SEM}, n=$ number of placentas).
0.05 ) increased $\mathrm{K}_{\mathrm{mf}}{ }^{51} \mathrm{Cr}$-EDTA (as compared to saline diluent), but only in two experimental collection periods (Fig. $4 A$ ). Perfusion with saline diluent in these experiments did significantly $(p<0.05)$ increase $\mathrm{K}_{\mathrm{mf}}{ }^{45} \mathrm{Ca}$ above control values in the first three experimental collection periods; this may have been due to unsteady state as unlike any of the other control periods, the $\mathrm{K}_{\mathrm{mf}}{ }^{45} \mathrm{Ca}$ showed a significant $(p<0.01)$ increase between the first (4-8 $\mathrm{min}$ ) and the second (8-12 min) control period. However, the increase in $\mathrm{K}_{\mathrm{mf}}^{45} \mathrm{Ca}$ seen with forskolin perfusion was still significantly $(p<0.05)$ greater than that with saline diluent in the three middle experimental collection periods (Fig. $4 B$ ).

Figures $5 A$ and $B$ show dose response curves of placentas from intact fetuses for forskolin constructed by taking the maximum percentage change from control found in the five forskolin/saline perfused collection periods of each experiment and plotting the mean of these for each dose. $\mathrm{K}_{\mathrm{mf}}{ }^{51} \mathrm{Cr}$-EDTA was unaffected by forskolin perfusion at any dose when compared with saline (Fig. $5 A$ ). The two highest concentrations, $10^{-5}$ and $10^{-4} \mathrm{M}$ forskolin showed a significant $(p<0.01)$ stimulation of $\mathrm{K}_{\mathrm{mf}}{ }^{45} \mathrm{Ca}$ above control levels as compared to saline diluent (Fig. 5B).

\section{DISCUSSION}

Viability of preparation. Perfusion of the fetal circulation of the rat placenta provides a simple means of measuring calcium transfer and of administering hormones to the fetal side, and in the rat (16), unlike the guinea pig (21), permeability to hydrophilic nonelectrolytes does not alter with perfusion. Similarly Stulc and Štulcová (15) demonstrated that almost identical values for $\mathrm{K}_{\mathrm{mf}}{ }^{45} \mathrm{Ca}$ across the intact and the perfused rat placenta and our $\mathrm{K}_{\mathrm{mf}}$ values for ${ }^{45} \mathrm{Ca}$ in placentas from normal fetuses are similar to theirs. Evidence for active calcium transfer during perfusion comes from the fact that cyanide can markedly reduce calcium transfer (15). Our findings reported here that $\mathrm{K}_{\mathrm{mf}}{ }^{45} \mathrm{Ca}$ is 20- to 30 -fold higher than the $\mathrm{K}_{\mathrm{mf}}$ for the extracellular marker ${ }^{51} \mathrm{Cr}$-EDTA, whereas their diffusion coefficients are only 2- to 3fold different, are compatible with such a conclusion and the observation that $\mathrm{K}_{\mathrm{mf}}{ }^{45} \mathrm{Ca}$ here is more than 2 -fold that of ${ }^{22} \mathrm{Na}$ (16), an ion with a smaller diffusion radius, is also compatible with active calcium transfer.

Use of $K_{m f}$. Ideally we would like to know the effect of hormonal interventions on both the affinity and the maximum velocity of the rate limiting element of the calcium active transport process (22). Such a kinetic analysis would require a design in which maternal plasma calcium could be easily manipulated; impossible with an intact maternal circulation. However, as net transplacental calcium flux is almost equal to $\mathrm{J}_{\mathrm{mr}} \mathrm{Ca}$ in the rat (15), net calcium accretion will depend on $\mathrm{J}_{\mathrm{m}} \mathrm{Ca}$ which will be a linear function of $\mathrm{K}_{\mathrm{mf}}{ }^{45} \mathrm{Ca}$, provided that flow limitation is unimportant and that maternal plasma calcium concentration is constant (22). This latter requirement was rendered invalid in one series of experiments by the unexpected observation that $\mathrm{MiCa}$ was significantly higher when the fetus had received a bPTH(1-84) injection. [Most reports in the literature suggest that PTH does not cross the placenta, at least from mother to fetus (5), although such impermeability is unlikely to be an all or none phenomenon. Our experiments suggest that either enough PTH can cross the placenta from fetus to mother to have an effect or that PTH perhaps stimulates increased synthesis by the fetal kidneys and placenta of $1,25(\mathrm{OH})_{2} \mathrm{D}_{3}$, which crosses to the mother and causes a rise in MiCa (23).] However, bPTH(1-84) increased calculated $\mathrm{K}_{\mathrm{mf}}^{45} \mathrm{Ca}$ and an increase in MiCa could be predicted to reduce $\mathrm{K}_{\mathrm{mf}}{ }^{45} \mathrm{Ca}$ in the absence of any change in placental calcium transfer kinetics. If anything, we will have underestimated the effect of bPTH(1-84) on the placental calcium transport mechanism.

Effect of decapitation. Although fetal decapitation is a gross surgical intervention with a high failure rate in terms of fetal death in utero and sometimes maternal loss, it can result in live 
fetuses which are hypocalcemic and whose plasma calcium may be returned to normal by PTH injection, as shown here and previously (24). Due to the substantial difference between decapitated and control fetuses we do not place great reliance on direct comparison between these two groups as any effects may be due to surgery in general, rather than parathyroidectomy alone. By contrast, the effects of injection or perfusion with specific drugs or hormones within each group, seem worthy of greater consideration.

Role of fetal PTH in control of placental Ca transfer. It has been suggested that fetal PTH plays a role in the generation of the "uphill" maternofetal calcium gradient $(24,25)$, but it is not clear whether fetal PTH acts solely on fetal bone and kidney or whether it influences directly the putative placental calcium transporter.

In this study, the bioactivity of both molecules of PTH was confirmed before use although we have no measure of the actual amount of PTH in the fetal circulation after injection into fetuses. The doses used were chosen by their ability to raise FiCa several hours after injection into intact fetuses. bPTH(1-84) increased $\mathrm{FiCa}$ in both intact and decapitated fetuses. In intact fetuses this was probably due to a direct action on fetal bone rather than any placental effect and in decapitated fetuses may also have been partly due to a bone effect. It was only in the placentas from decapitated fetuses that bPTH(1-84) had a stimulatory effect on $\mathrm{K}_{\mathrm{mf}}{ }^{45} \mathrm{Ca}$, i.e. where the clearance was low to start with. However, even here, bPTH(1-84) still did not stimulate maternofetal calcium clearance back to normal. This either reflects a response to the gross fetal surgery or suggests only a permissive effect of this hormone on maternofetal calcium transfer in the rat. In these experiments, bPTH(1-84) could be acting either directly on the placental calcium transporter or via stimulation of the fetal kidney to synthesize $1,25(\mathrm{OH})_{2} \mathrm{D}_{3}$.

Perfusion with $\mathrm{r}\left[\mathrm{Nle}^{8,21}, \mathrm{Tyr}^{34}\right] \mathrm{PTH}(1-34)$ was carried out to investigate whether PTH was having a direct effect on the placenta, but it seemed to have no effect on $\mathrm{K}_{\mathrm{mf}}{ }^{45} \mathrm{Ca}$ in either preparation despite being effective in raising FiCa. Either the effect of bPTH(1-84) injection in decapitated fetuses on placental calcium transfer was solely due to increased production of $1,25(\mathrm{OH})_{2} \mathrm{D}_{3}$ or the course of action of PTH is too slow to show up in a 40 -min perfusion period, or $\mathrm{r}\left[\mathrm{Nl}^{8,21}, \mathrm{Tyr}^{34}\right] \mathrm{PTH}(1-34)$ is less active on the placenta than bPTH(1-84).

Role of fetal 1,25(OH) ${ }_{2} \mathrm{D}_{3}$ in control of placental $\mathrm{Ca}$ transfer. Other workers have reported fetal blood hypercalcemia in response to $1,25(\mathrm{OH})_{2} \mathrm{D}_{3}$ in sheep and rats $(26,27)$. Chalon and Garel (27) injected approximately $2 \mathrm{ng} 1,25(\mathrm{OH})_{2} \mathrm{D}_{3}$ into 19 -d gestation rat fetuses and found an increase in FiCA by d 21 , when compared to noninjected fetuses. The higher dose of $20 \mathrm{ng}$ $1,25(\mathrm{OH})_{2} \mathrm{D}_{3}$ used here had no effect on FiCa after $2 \mathrm{~h}$, but it could be that this time course was too short to observe a response. The effect of $1,25(\mathrm{OH})_{2} \mathrm{D}_{3}$ in this respect, was clearly quite different to that of $\mathrm{bPTH}(1-84)$ which did increase $\mathrm{FiCa}$ within $2 \mathrm{~h}$.

The effect of fetally injected $1,25(\mathrm{OH})_{2} \mathrm{D}_{3}$ on $\mathrm{K}_{\mathrm{mf}}{ }^{45} \mathrm{Ca}$ was similar to that of bPTH(1-84), in that there was stimulation, but only in placentas from decapitated fetuses. However, unlike $\mathrm{r}\left[\mathrm{Nle}^{8,21}, \mathrm{Tyr}^{34}\right] \mathrm{PTH}(1-34), 1,25(\mathrm{OH})_{2} \mathrm{D}_{3}$ also stimulated maternofetal calcium clearance when perfused through the placentas of these decapitated fetuses. This provides some evidence for the idea that the in vivo effect of PTH is via $1,25(\mathrm{OH})_{2} \mathrm{D}_{3}$. The dose of $1,25(\mathrm{OH})_{2} \mathrm{D}_{3}$ used for perfusion experiments was close to the reported fetal plasma levels of $1,25(\mathrm{OH})_{2} \mathrm{D}_{3}(28)(54.7 \mathrm{pg} / \mathrm{mL})$ and the suggestion of a placental effect of $1,25(\mathrm{OH})_{2} \mathrm{D}_{3}$ is also supported by the presence of $1,25(\mathrm{OH})_{2} \mathrm{D}_{3}$ receptors in the rat placenta (29). 1,25(OH) $)_{2} \mathrm{D}_{3}$ (like bPTH 1-84) did not return calcium clearance back to normal levels in placentas of decapitated fetuses and, together with the lack of effect on placentas of intact fetuses, again suggests that the hormone may only have a permissive effect on placental transport.

Effects of forskolin in perfused rat placenta. Perfusion of for- skolin through placenta of intact fetuses clearly increased $\mathrm{K}_{\mathrm{mf}}{ }^{45} \mathrm{Ca}$ in a dose-dependent fashion. The probable EC50 between $10^{-6}$ and $10^{-5} \mathrm{M}$ apparent in Figure $5 B$ is consistent with the potency found for raising cAMP levels in other tissues (17). The effect of forskolin in these placentas seemed to be specific to calcium transfer, as the clearance of ${ }^{51} \mathrm{Cr}$-EDTA was not altered. This specificity was less clear in placentas from decapitated fetuses, in whom clearances of both ${ }^{51} \mathrm{Cr}$-EDTA and ${ }^{45} \mathrm{Ca}$ were increased. It could be that forskolin has nonspecific effects in the placenta, e.g. increasing blood flow (forskolin decreases placental vascular resistance in the rabbit) (30) or passive permeability, which are of greater importance to those placentas from decapitated fetrises. However, this requires further investigation. As with $\mathrm{bPT}_{2} \mathrm{f}^{\mathrm{N}}$ 84) and $1,25(\mathrm{OH})_{2} \mathrm{D}_{3}$, forskolin did not increase $\mathrm{K}_{\mathrm{mf}}{ }^{45} \mathrm{Ca}$ back to normal levels in placentas from decapitated fetuses, and this might suggest that surgery per se does affect the calcium transporter.

It is clear that the effects of forskolin are quite different from those of PTH and $1,25(\mathrm{OH})_{2} \mathrm{D}_{3}$. In particular, the diterpene was able to stimulate maternofetal calcium transport across placentas from intact fetuses to supranormal levels. This therefore suggests that at least one further hormone (which forskolin mimics) acutely regulates placental calcium transfer in vivo; perhaps the recently reported PTHrP (3) or calcitonin (2). An alternative possibility is a direct (independent of cAMP) action of forskolin on calcium channels in this system similar to its reported effect on voltage-gated $\mathrm{K}^{+}$channels in a clonal pheochromocytoma cell line (31).

Acknowledgments. The authors are grateful to Dr. P. D. Davies of Roche Products for donating the $1,25(\mathrm{OH})_{2} \mathrm{D}_{3}$.

\section{REFERENCES}

1. Barlet J-P 1985 Prolactin and calcium metabolism in pregnant ewes. J Endocrinol 107:171-175

2. Barlet J-P 1985 Calcitonin may modulate placental transfer in ewes. J Endocrinol 104:17-21

3. Rodda CP, Kubota M, Heath JA, Ebeling PR, Moseley JM, Care AD, Caple IW, Martin TJ 1988 Evidence for a novel parathyroid hormone-related protein in fetal lamb parathyroid glands and sheep placenta: comparisons with a similar protein implicated in humoral hypercalcaemia of malignancy. J Endocrinol 117:261-271

4. Care AD, Ross R 1984 Fetal calcium homeostasis. J Dev Physiol 6:59-66

5. Garel J-M, Dumont C 1972 Distribution and inactivation of labelled parathyroid hormone in the rat fetus. Horm Metab Res 4:217-221

6. Garel J-M, Milhaud G, Sizonenko P 1969 Thyrocalcitonine et barriere placentaire chez le rat. CR Acad Sci Serie D269:1785-1787

7. Balabanova S, Grobeloh F, Reinhardt G 1987 Immunoreactive parathyroid hormone secretion by human placental tissue. Calcif Tissue Int 41 (suppl 2):37(abstr)

8. Balabanova S, Kruse B, Wolf AS 1987 Calcitonin secretion by human placental tissue. Acta Obstet Gynecol Scand 66:323-326

9. Thomas ML, Anast CS, Forte LR 1981 Regulation of calcium homeostasis in the fetal and neonatal rat. Am J Physiol 240:E367-372

10. Garel J-M, Besnard P, Rebut-Bonneton C 1981 C cell activity during prenatal and postnatal periods in the rat. Endocrinology 109:1573-1577

11. Haddad JG Jr, Boisseau V, Avioli LV 1971 Placental transfer of vitamin $D_{3}$ and 25-hydroxycholecalciferol in the rat. Lab Clin Med 77:908-915

12. Tanaka Y, Frank H, DeLuca HF 1972 Role of 1,25-dihydroxycholecalciferol in calcification of bone and maintenance of serum calcium concentration in the rat. J Nutr 102:1569-1577

13. Weisman Y, Sapir R, Harell A, Edelstein S 1976 Maternal-perinatal interrelationships of vitamin D metabolism in rats. Biochim Biophys Acta 428:388 395

14. Ross R, Care AD, Robinson JS, Pickard DW, Weatherley AJ 1980 Perinatal 1,25-dihydroxychloecalciferol in the sheep and its role in the maintenance of the transplacental calcium gradient. J Endocrinol 87:17-18

15. Štulc J, Stulcová B 1986 Transport of calcium by the placenta of the rat. J Physiol (Lond) 371:1-16

16. Robinson NR, Atkinson DE, Jones CJP, Sibley CP 1988 Permeability of the near term rat placenta to hydrophilic solutes. Placenta 9:361-372

17. Seamon KB, Daly JW 1981 Forskolin: a unique diterpene activator of cyclic AMP-generating systems. J Cyclic Nucleotide Protein Phosphor Res 7:201224

18. Jost A 1947 Experiences decapitation de l'embryon de Labin. C R Acad Sci Serie B 225:322-324

19. Rosenblatt M, Golzman D, Keutmann HT, Tregear GW, Potts JT 1976 Chemical and biological properties of synthetic, sulfur-free analogues of parathyroid hormone. J Biol Chem 251-164 
20. Bikle DD, Siiteri PK, Ryzen E, Haddad JG 1985 Serum protein binding of 1,25-dihydroxyvitamin $\mathrm{D}$ : a reevaluation by direct measurement of free metabolite levels. J Clin Endocrinol Metab 61:969-975

21. Hedley R, Bradbury MWB 1980 Transport of polar non-electrolytes across the intact and perfused guinea-ping placenta. Placenta 1:277-285

22. Sibley CP, Boyd RDH 1988 Control of transfer across the mature placenta. In Clarke JR (ed) Oxford Reviews of Reproductive Biology, Vol 10. Oxford University Press, pp 382-435

23. Ross R, Care AD, Robinson JS, Pickard JS, Weatherley AJ 1981 Perinatal $1,25(\mathrm{OH})_{2} \mathrm{D}_{3}$ in the sheep; involvement of fetal $1,25(\mathrm{OH})_{2} \mathrm{D}_{3}$ in the maintenance of the transplacental calcium gradient. In: Cohen DV, Talmage RV, Matthews, JL (eds) Hormonal Control of Calcium Metabolism. Excerpta Matthews, JL (eds) Hormonal Con

24. Garel J-M, Pic J, Jost A 1971 Action de la parathormone chez le foetus de rat. Ann Endocrinol 32:253-262

25. Garel J-M 1970 Effet de l'injection d'un serum 'antiparathormone' chez le foetus de rat. C R Acad Sci Serie D271:2364-2366

26. Barlet J-P, Davicco M-J, LeFaivre J, Garel J-M 1978 Endocrine regulation of plasma phosphate in sheep fetuses with catheters implanted in utero. In Massry SG, Ritz E, Rapado A (eds) Homeostasis of Phosphate and Other Minerals. Plenum Press, New York, pp 243-256

27. Chalon S, Garel J-M 1983 1,25-dihydroxyvitamin $\mathrm{D}_{3}$ injections into rat fetuses: effects on fetal plasma calcium, plasma phosphate and mineral content. Reprod Nutr Dev 23:567-573

28. Verghaeghe J, Bouillon R, Njomba BL, Lissens W, Van Assche FA 1986 Vitamin $\mathrm{D}$ and bone mineral homeostasis during pregnancy in the diabetic BB rat. Endocrinology 118:1019-1025

29. Pike JW, Gooze LL, Haussler MR 1980 Biochemical evidence for 1,25dihydroxyvitamin $\mathrm{D}$ receptor macromolecules in parathyroid, pancreatic, pituitary and placental tissues. Life Sci 26:407-414

30. Reid DL, Hollister MC, Phernetton TM, Rankin JHG 1988 Effects of forskolin on placental vascular resistance in rabbits. Proc Soc Exp Biol Med 188:451454

31. Hoshi T, Garber SS, Aldrich RW 1988 Effect of forskolin on voltage-gated K+ channels is independent of adenylate cyclase activation. Science 240:16521655 